\title{
Justiciability, Access to Justice and the Development of Constitutional Law in Canada
}

Lorne Sossin

Osgoode Hall Law School of York University, Isossin@osgoode.yorku.ca

Gerard J. Kennedy

Source Publication:

45(4) Federal Law Review 707

Follow this and additional works at: https://digitalcommons.osgoode.yorku.ca/scholarly_works

Part of the Constitutional Law Commons

\section{Repository Citation}

Sossin, Lorne and Kennedy, Gerard J., "Justiciability, Access to Justice and the Development of Constitutional Law in Canada" (2017). Articles \& Book Chapters. 2671.

https://digitalcommons.osgoode.yorku.ca/scholarly_works/2671

This Article is brought to you for free and open access by the Faculty Scholarship at Osgoode Digital Commons. It has been accepted for inclusion in Articles \& Book Chapters by an authorized administrator of Osgoode Digital Commons. 


\section{HEINONLINE}

Citation:

Gerard J. Kennedy; Lorne Sossin, Justiciability, Access to Justice and the Development of Constitutional Law in Canada, 45 Fed. L. Rev. 707 (2017)

Provided by:

Osgoode Hall Law School Library

Content downloaded/printed from $\underline{\text { HeinOnline }}$

Mon Feb 12 09:40:01 2018

-- Your use of this HeinOnline PDF indicates your acceptance of HeinOnline's Terms and Conditions of the license agreement available at http://heinonline.org/HOL/License

-- The search text of this PDF is generated from uncorrected OCR text.

-- To obtain permission to use this article beyond the scope of your HeinOnline license, please use:

\section{Copyright Information}

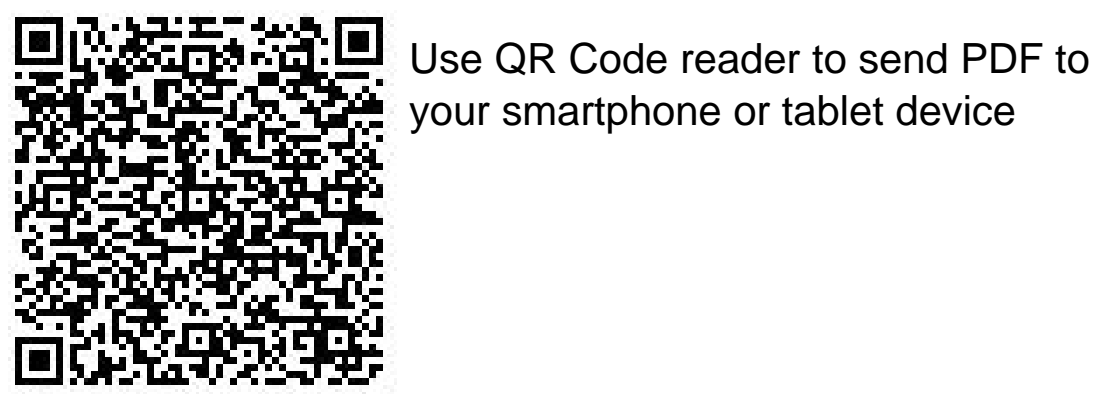




\title{
JUSTICIABILITY, ACCESS TO JUSTICE AND THE DEVELOPMENT OF CONSTITUTIONAL LAW IN CANADA
}

\author{
Gerard J Kennedy and Lorne Sossin ${ }^{* *}$
}

\begin{abstract}
Concentrating on Canadian experience, specifically litigation under the Canadian Charter of Rights and Freedoms (the 'Charter'), this article seeks to reconcile the access to justice benefits of summary procedures with the government litigant's duty to act in the public interest (or as a 'model litigant') and uphold the rule of law. Though acknowledging the benefits that can result from the use of summary procedures to end litigation, the authors observe that compliance with strict requirements in procedural law are frequently dispensed with in the Charter context. In fact, summary procedures can have a devastating effect on the development of Charter rights. The authors ultimately posit that the government should have a duty of restraint in using summary procedures to end public law litigation, and courts should be reluctant to permit the government to preclude such litigation aimed at advancing the evolution of the Charter from reaching hearings on the merits.
\end{abstract}

\section{INTRODUCTION}

This edition of this journal addresses the 'boundaries of judicial review'. Traditionally, this concerns the concept of justiciability. ${ }^{1}$ If a case raises a question that a court is institutionally incapable of answering, or that is not susceptible to the judicial process, litigation is foreclosed by the courts as part of their gatekeeping function. In this paper, we look at justiciability from a different angle, one which can functionally determine whether litigation can proceed - the boundaries of the use of summary procedures to end public law litigation (including judicial review).

Just as there is no right without a remedy, so it means little to say a matter is justiciable if a party is effectively precluded from advancing it to a decision on the merits. Using Canada as a case study, and concentrating on litigation under the Canadian Charter of Rights and Freedoms, ${ }^{2}$ we explore the relationship between procedural justice and justiciability. We seek to reconcile the access to justice benefits that can result from

\footnotetext{
* Ph.D. Candidate, Osgoode Hall Law School, York University; 2016 Pierre Elliott Trudeau Foundation Scholar.

** Dean and Professor, Osgoode Hall Law School, York University.

1 See, eg, Lorne M Sossin, Boundaries of Judicial Review: The Law of Justiciability in Canada (Carswell, 2nd ed, 2012).

2 Canada Act 1982 (UK) c 11, sch B pt I ('Charter').
} 
summary procedures with the government litigant's duty to act in the public interest (or as a 'model litigant') and uphold the rule of law.

The Supreme Court of Canada has acknowledged that access to justice is one of the least admirable aspects of Canada's justice system, and a serious threat to the rule of law. ${ }^{3}$ Courts in Canada and specifically Ontario have encouraged the creative and novel uses of civil procedure to summarily end proceedings in order to improve access to justice. ${ }^{4}$ But summary procedures are not without their disadvantages, such as risking advantaging heavily resourced parties ${ }^{5}$ and denying parties their 'day in court'. ${ }^{6}$ These concerns are heightened when a government litigant considers using the summary procedure to end a litigation. Government litigants are not only exceptionally wellresourced, but they also have a public interest mandate, particularly in Charter matters. ${ }^{7}$ Moreover, the use of summary procedures to end Charter litigation can have devastating effects.

In Part II of this paper, we briefly explain principles of constitutional litigation in Canada and how they differ in important ways from those in Australia. We then explore the relationship between justiciability and access to justice, and provide a brief overview the crisis of access to justice facing the courts in Canada. We also explore civil rules reform (particularly with respect to summary procedures to end civil actions) as one strategy adopted by Canadian jurisdictions to address this crisis. In Part III, we explain why greater flexibility regarding procedural matters in Charter cases may be justified. In Part IV, we note the negative consequences that can arise from the use of procedural tactics in Charter matters, especially when employed against poorly resourced parties. In Part V, based on the foregoing, we explain why we view it as appropriate to recognise a duty of constraint on government lawyers employing summary procedures to end Charter litigation, and why courts should be reluctant to allow the government to end such litigation through summary procedures. This will not require much nuancing of established principles of and rules within procedural law. Indeed, the rule of law - one of the principles that supports the expanded use of summary procedures to end litigation in a purely private context-may point in precisely the opposite direction in the public law, and specifically Charter, context.

3 See, eg, Hryniak v Mauldin [2014] 1 SCR 87, 92 [1] (Karakatsanis J) ('Hryniak').

$4 \quad$ Ibid

5 See, eg, Michelle Flaherty, 'Best Practices in Active Adjudication' (2015) 28 Canadian Journal of Administrative Law and Practice 291, 297-8. The pitfalls facing self-represented litigants are explained thoroughly by Julie Macfarlane in Julie MacFarlane, 'The National SelfRepresented Litigants Project: Identifying and Meeting the Needs of Self-Represented Litigants' (Final Report, Treasurer's Advisory Group on Access to Justice, May 2013) < http://www.lsuc.on.ca.ezproxy.library.yorku.ca/uploadedFiles/For_the_Public/About_th e_Law_Society/Convocation_Decisions/2014/Self-represented_project.pdf $>$.

6 Vasuda Sinha, Lorne Sossin and Jenna Meguid, 'Charter Litigation, Social and Economic Rights \& Civil Procedure' (2017) 26 Joumal of Law and Social Policy 43; Jonathan Lisus, 'Hryniak: Requiem for the vanishing trial, or brave new world?' (2014) 33(1) The Advocates' Journal 6.

7 Adam M Dodek, 'Lawyering at the Intersection of Public Law and Legal Ethics: Government Lawyers as Custodians of the Rule of Law' (2010) 33(1) Dalhousie Law Journal 1. 


\section{CANADIAN CONSTITUTIONAL LITIGATION, JUSTICIABILITY, ACCESS TO JUSTICE AND PROCEDURAL LAW}

\section{A Justiciability in Canadian Law}

As in Australia, ${ }^{8}$ judicial review is constitutionally guaranteed in Canada to uphold the rule of law. ${ }^{9}$ As Justice Ivan Rand famously wrote in 1959's Roncarelliv Duplessis, 'there is no such thing as absolute and untrammelled "discretion" in exercising public powers. ${ }^{10}$ Despite these general principles in Canadian law, the doctrine of justiciability demarcates the scope of judicial review. Consistent with Rayner Thwaites's conceptualisation, justiciability may extend further to administrative schemes directed at making the actions they cover non-justiciable. ${ }^{11}$

In the Canadian context, where a matter raises no legal dispute, or is otherwise inappropriate to adjudicate (whether because the dispute has been allocated to another body such as Parliament to resolve or because the matter is not yet ripe or already moot), a judge generally will decline to hear the matter as it is non-justiciable. Though an important doctrine that recognises the limits of judicial power, justiciability can also be seen as the effective limits of the rule of law in a society. Parties to disputes held to lie outside of the province of the courts to adjudicate are left without recourse to assure the rule of law is respected. ${ }^{12}$

Non-justiciable matters per se are relatively rare in Canadian law, related to matters such as exercises of Crown prerogative, including advice that the Prime Minister gives to the Queen or her representatives concerning the bestowing of honours. ${ }^{13}$ As we return to below, some kinds of claims for social and economic rights may also be nonjusticiable. ${ }^{14}$ This is very different than in Australia, where many 'margin cases' concern migration. ${ }^{15}$ Unlike Australia, ${ }^{16}$ advisory opinions are permissible in Canadian law. ${ }^{17}$ Public interest standing can be granted to ensure that judicial review of government

8 Explained in Matthew Groves, 'Judicial Review and Human Rights' (2018) 25 Australian Journal of Administrative Law (forthcoming), citing Plaintiff S157/2002 v Commonwealth (2003) 211 CLR 476, 513 [103].

9 Described in a series of cases beginning with Crévier v A-G (Quebec) [1981] 2 SCR 220 (Laskin $\mathrm{CJ})$. The constitutional requirement for judicial review is also noted by Abella $\mathrm{J}$ in Wilson $v$ Atomic Energy of Canada Ltd [2016] 1 SCR 770, 794-5 [31].

10 [1959] SCR 121, 140.

11 Rayner Thwaites, 'The Changing Landscape of Non-Justiciability' [2016] 1 New Zealand Law Review 31, 59.

12 For further discussion of this point, see Lorne Sossin, 'The Unfinished Project of Roncarelli: Justiciability, Discretion and the Limits of the Rule of Law' (2010) 55(3) McGill Law Journal 661.

13 See, eg, Black v Chrétien (2001) 54 OR (3d) 215 (CA).

14 Tanudjaja v A-G (Canada) (2014) 123 OR (3d) 161 ('Tanudjaja').

15 See, eg, Groves, above $n$ 8, citing Stephen Gageler, 'Impact of Migration Law on the Development of Australian Administrative Law' (2010) 17 Australian Journal of Administrative Law 92.

16 See, eg, Matthew Groves, 'Judicial Review of Administrative Action in the High Court of Australia' (2008) 33(2) Queen's Law Journal 327, 347-8; In re Judiciary and Navigation Acts (1921) 29 CLR 257.

17 See, eg, Reference re Secession of Quebec [1998] 2 SCR 217. 
action is not illusory, ${ }^{18}$ and Canadian courts will even entertain ' moot' $^{\prime}$ matters where the live dispute between the parties is over, but there is a public interest in resolving a point of law. ${ }^{19}$ This makes the Canadian experience very different than Australian concerns about the defining the 'matter' in a judicial review proceeding. ${ }^{20}$

What is less clear is the status of those matters which in theory can be adjudicated, but where practical barriers lead to them effectively being outside the province of the courts. Traditionally, such areas are examined through the lens of access to justice - the matrix of personal, situational, and institutional and systemic factors which make certain matters and certain litigants less likely to be heard in court. The relationship between justiciability and access to justice remains both under-theorised and under-scrutinised. This article is an attempt to address this lacuna.

Our argument is that access to justice may be considered as a dimension of justiciability (and vice versa). This perspective does not necessarily entail seeing every question of how courts are accessed as a matter of justiciability. The tort of negligence is justiciable even if we know the cost of competent legal representation may put the enforcement of tort rights out of reach for many middle and low-income community members. By the same token, disputes about the tenets of religious faiths may be nonjusticiable even where parties have the patience and resources to see through the litigation process. Access to justice and justiciability remain distinct spheres which shape the justice system. Rather, we argue there is an overlapping sphere where justiciability and access to justice interact and reinforce one another. In this article, we suggest litigation under the Canadian Charter represents one such overlapping sphere.

Justiciability construed in this broader way, as including where relevant an access to justice dimension, cannot be defined simply as the matters which a court will adjudicate, but also the matters which effectively can be brought to court. In this sense, justiciability should include an analysis of courts, but also an analysis of the rules governing the litigation process, as well as an analysis of the parties who come to court, and the barriers they may face.

\section{B Conceptualizing Access to Justice}

Precisely what the phrase 'access to justice' encompasses varies according to the circumstances. Access to justice often is expressed as access to lawyers and courts. Under this view, services such as pro bono legal services and legal aid provide a means for individuals to access formal dispute resolution mechanisms like courts where they would otherwise be unable to do so. Another example would be the waiver of court hearing fees for individuals without the financial means to pay, thus helping all persons access the courts..$^{21}$ Another broader conception, however, is that access to justice is not 'just about access to the courts but also about access to markets and regulatory regimes that would lessen the need for access to the courts' ${ }^{22}$ This broader approach to access to

18 A-G (Canada) v Downtown Eastside Sex Workers United Against Violence Society [2012] 2 SCR 524 ('Downtown Eastside').

19 Borowski v A-G (Canada) [1989] 1 SCR 342 ('Borowski').

20 See, eg, Groves, above n 16, 347-8; Re McBain; ex parte Australian Catholic Bishops Conference (2002) 209 CLR 372, 458-62 [242]-[252] (Hayne J).

21 Trial Lawyers Association of British Columbia v A-G (British Columbia) [2014] 3 SCR 31 ('Trial Lawyers Association').

22 Kent Roach and Lorne Sossin, 'Access to Justice and Beyond' (2010) 60(2) University of Toronto Law Journal 373,374 . 
justice embraces the adoption of innovations in the traditional justice system, such as small claims courts, class actions, and online dispute resolution. ${ }^{23}$ They allow a greater number of individuals to seek legal remedies. ${ }^{24}$ Access to justice in this sense is not only about enabling individuals to access means of legal remedies (as with the first two conceptions), but also about breaking down the barriers that often prevent people from ensuring their legal rights are respected.

At its most holistic, understanding these barriers will include normative questions about what values constitute 'justice' and ensuring that the substantive law encompasses such values. ${ }^{25}$ But at the very least, it means that civil litigation should have three characteristics: minimal financial costs, timeliness, and simplicity. ${ }^{26}$ Strong arguments can be made that such an understanding of access to justice is too narrow. ${ }^{27}$ Nonetheless, these virtues are unquestionably part of a proper understanding of access to justice. ${ }^{28}$

Based on these values, Ontario amended its Rules of Civil Procedure effective January 1, 2010 (the '2010 Amendments'). ${ }^{29}$ The 2010 Amendments were the beginning of an effort to amend the Rules to promote the resolution of lawsuits in a manner that minimises delay and expense. ${ }^{30}$ In its seminal 2014 decision Hryniak $v$ Mauldin, the Supreme Court held that the 2010 Amendments should be interpreted generously to achieve access to justice. This is consistent with enshrining of the value of proportionality in the Rules. 31

Amending civil procedure is surely not a catch-all solution to access to justice problems. Indeed, an excessive emphasis on civil procedure can even be an impediment to more holistic understandings of access to justice..$^{32}$ But once civil procedure is guiding an action through the court system, it is useful and appropriate to assess whether that civil procedure is leading to resolution of that action promptly and with minimal

23 Civil Resolution Tribunal <https://civilresolutionbc.ca/>; Shannon Salter, 'ODR and Justice System Integration: B.C.'s Civil Resolution Tribunal' (2017) 34(1) Windsor Yearbook of Access to Justice 112.

24 Roach and Sossin, above $\mathrm{n} 22,376$.

25 See, eg, Trevor C.W. Farrow, 'What is Access to Justice?' (2014) 51(3) Osgoode Hall Law Journal 957, 970-2.

26 Ibid, 978-9; Roderick A Macdonald, 'Access to Justice in Canada Today: Scope, Scale and Ambitions' in Julia Bass, W A Bogart and Frederick H Zemans (eds), Access to Justice for a New Century - The Way Forward (Irwin Law, 2005) 68-73. Underlying all of these, as well as an important principle in its own right, is proportionality: Hryniak [2014] 1 SCR 87, [29]-[33]; Trevor Farrow, 'Proportionality: A Cultural Revolution' (2012) 1 Joumal of Civil Litigation and Practice 151.

27 See, eg, Trevor C.W. Farrow, 'A New Wave of Access to Justice Reform' in Adam Dodek and Alice Woolley (eds), In Search of the Ethical Lauyer: Stories from the Canadian Legal Profession (UBC Press, 2016) 164, 166-7; Andrew Pilliar, 'Exploring a Law Firm Business Model to Improve Access to Justice' (2015) 32(1) Windsor Yearbook of Access to Justice 1.

28 Farrow, above n 27, 166-7.

29 Rules of Civil Procedure, RRO 1990, Reg 194 ('Rules').

30 See, eg, O Reg 43/14; O Reg 438/08.

31 Rules, RRO 1990, Reg 194, r 1.04(1.1) as inserted by O Reg, 438/08, s 2. See Farrow, above n 26.

32 Farrow, above n 27, 167. 
financial expense. This work is complementary, rather than an alternative, to analyses of broader issues affecting access to justice. ${ }^{33}$

There are three aspects of Ontario's procedural law that have arguably changed in recent years, with the goal of contributing to prompt, summary resolutions of civil claims on their merits: 1) summary judgment; 2) motions to strike; and 3) dismissals sua sponte. We discuss each in turn.

\section{Summary Judgment}

Hryniak concerned likely the most notable of the 2010 Amendments - the expanded power of courts to grant 'summary judgment'. This allows a court to dispose of all or part of a case on a motion, with affidavit evidence, and without a full trial. ${ }^{34}$ Any party may bring a summary judgment motion to resolve an action promptly. Despite historic reluctance to grant 'summary judgment', the Supreme Court of Canada ruled in Hryniak that summary judgment powers are to be interpreted broadly to promote access to justice. ${ }^{35}$ Hryniak was generally praised, ${ }^{36}$ but its effects are only beginning to be analyzed. Shantona Chaudhary 37 and Brooke MacKenzie ${ }^{38}$ have argued that Hryniak's expansion of summary judgment powers has a strong theoretical foundation and has had positive empirical effects.

Summary judgment remains available in constitutional law cases and is sought by the Crown or other public bodies as defendants in instances such as there being no evidence to support a claim ${ }^{39}$ or a binding release having been signed. ${ }^{40}$ One Ontario judge, when dismissing a motion to strike a Charter claim, recently suggested that a summary judgment motion would have been more appropriate. ${ }^{41}$

\section{The Motion to Strike}

The motion to strike (in Ontario, Rule 21 of the Rules) allows a Court to dispose of a case because it does not disclose a cause of action. This could be because the action is frivolous, vexatious, or an abuse of the Court's process. ${ }^{42}$ It could also be the result of the plaintiff's claim failing to disclose a cause of action because she pleads facts that, even if accepted as true, would not entitle her to the relief she is seeking; in this sense, an action that fails to plead a cause of action is an abuse of process. ${ }^{43}$ Importantly, the record is said to be less significant in motions to strike because the premise of such a motion is that all the facts must be considered as proven. This approach makes sense in the context of common law contexts such as tort and contract breaches. For example, if

33 Tbid 166.

34 Rules, RRO 1990, Reg 194, r 20, as analysed in Hryniak [2014] 1 SCR 87.

35 Hryniak [2014] 1 SCR 87, 93 [5].

36 See, eg, Shantona Chaudhary, 'Hryniak v. Mauldin: The Supreme Court issues a clarion call for civil justice reform' (2014) 33 The Advocates' Joumal 3.

37 Ibid

38 Brooke MacKenzie, 'Effecting a Culture Shift: An Empirical Review of Ontario's Summary Judgment Reforms' (2017) 54 Osgoode Hall Law Joumal 1275.

39 See, eg, Kasheke v A-G (Canada) (2017) 277 ACWS (3d) 75 (NSSC); Farley v Ottawa (City) Police Services Board (2017) 282 ACWS (3d) 690 (ONCA), as examples where this occurred.

40 See, eg, Sturgeon Lake Indian Band v A-G (Canada) (2016) 269 ACWS (3d) 201 (ABQB).

41 Smith v Ontario (2016) 368 CRR (2d) 322, [172] (Matheson J) (ONSC).

42 Rules, RRO 1990, Reg 194, r 21.01(3)(d).

43 Stephen Pitel and Matthew Lerner, 'Resolving Questions of Law: A Modern Approach to Rule 21' (2013) 43 Advocates' Quarterly 344, 348. 
the issue is whether tort law recognises a right to damages for 'nervous shock,' it would be unnecessary and arguably unfair to put the parties to the task of establishing a factual basis for nervous shock if this category of tortious harm is not recognised in the first place. In this sense, Rule 21 may be understood as an underutilised tool for facilitating access to justice and developing the common law in a principled and proportionate matter. ${ }^{44}$ Rule 21 per se was not amended in 2010, though the value of proportionality should apply to how it is interpreted, just as it applies to all elements of Ontario procedural law. ${ }^{45}$ Hryniak's call for a 'culture shift' in how civil litigation is conducted is also arguably relevant to the interpretation of this rule. ${ }^{46}$

As we discuss below, however, the same logic which animates civil justice disputes may not adhere in the context of the Charter.

3 Dismissals Sua Sponte

Ontario's Rules were once again amended in 2014 to allow a court to very summarilyeither on its own initiative or at the request of counsel-dismiss a claim that is 'on its face' frivolous, vexatious, or an abuse of process. ${ }^{47}$ This rule is 'not for close calls' ${ }^{48}$ given the 'on its face' requirement, defendants are not generally permitted to explain why the action should be dismissed. ${ }^{49}$ But this new rule does allow a Court to deal with vexatious litigants who, were a formal motion brought seeking to dismiss their claim, would merely treat the motion as a fresh opportunity to conduct the proceedings in a vexatious manner. ${ }^{50}$ Arguably, whatever the proper approach to procedural constraint under the Charter, it should not permit frivolous and vexatious matters to tie up judicial resources. ${ }^{51}$

\section{THE NEED FOR GREATER FLEXIBILITY IN CHARTER CASES}

These three procedural mechanisms may be used to prevent claims from going to trial. In many cases, they allow for parties to avoid the cost and delay associated with trials and ensure only those matters which need the judicial and institutional resources of a trial receive them. Applications under the Charter, however, raise different concerns. The Charter, which came into effect in 1982 following the patriation of Canada's Constitution from the United Kingdom, recognises a series of fundamental freedoms and rights which operate against the state.

All applicants who raise Charter challenges, by definition, engage the Crown as a party, and will be at a disadvantage against the Crown in terms of resources and patience. People grow old and die but the Crown does not. People can run out of money but the Crown cannot (in theory, at least, it can obtain additional funds through taxation which no private party can match). This imbalance risks disturbing equal access to

44 Gerard J Kennedy and Mary Angela Rowe, 'Tanudjaja v. Canada (Attorney General): Distinguishing Injusticiability and Deference on Motions to Strike' (2015) 44 Advocates' Quarterly 391. See also ibid.

Farrow, above $\mathrm{n} 26$.

Already discussed in Pitel and Lerner, above n 43; Kennedy and Rowe, above $n 44$.

Rules, RRO 1990, Reg 194, r 2.1 .

48 Raji v Ladner (2015) 248 ACWS (3d) 828, [9] (ONSC) ('Raji'); approved by the Court of Appeal in Scaduto $v$ Law Society of Upper Canada (2015) 343 OAC 87, [9].

49 Raji (2015) 248 ACWS (3d) 828, [12].

50 Ibid [8].

51 See, eg, Asghar v Ontario [2015] ONSC 4071 (23 June 2015). 
courts, and to law, which has been recognised by scholars in Canada and Australia as a practical threat to the rule of law as one's ability to live under the law will be affected by her economic status. ${ }^{52}$ The Supreme Court of Canada recognised this concern in Trial Lawyers Association, where it held that mandatory court service fees were unconstitutional. ${ }^{53}$ Thus, when it comes to the justiciability of Charter rights, we must be concerned both with the doctrinal scope of the Charter (as interpreted by the Courts) and with the litigation tactics and procedural avenues open to the parties, and in particular open to the Crown to deter or derail litigation seeking to assert, apply or expand Charter rights and freedoms. In this sense, we argue justiciability needs to be understood through the lens of the lived experience of those who seek judicial remedies.

Notwithstanding the access to justice benefits of summary procedures generally in civil litigation, there are three main arguments to support the proposition that it is inconsistent with the public interest for procedural mechanisms to be used as barriers in Charter and public standing litigation: 1) the Attorney General has special ethical duties to the public interest and rule of law; 2) the government itself provides financial support for Charter challenges and therefore should not actively seek to prevent Charter litigation from being decided on its merits; and 3) the Supreme Court of Canada has aimed to promote public standing litigation by adopting flexible standards for public interest standing and interim costs, and this same approach should inform the exercise of Crown discretion in relation to procedural challenges.

Procedural mechanisms, such as motions to strike, must be understood as having the capacity to undermine the development of Charter rights. In other words, in setting out the boundaries of judicial review, justiciability extends beyond the subject area limits of the judicial process to practical realities in that process as well. Understanding justiciability in this way, in our view, also leads to a rationale for principled constraints to be recognised on the Crown's discretion to raise procedural challenges at least to Charter test cases (if not to a broader set of public interest litigation), where doing so in effect would bar such cases from ever reaching a hearing on the merits.

\section{A Legal Ethics and Crown Discretion in Charter Cases}

The Attorney General occupies a unique role in that they are both the government's lawyer and the protector of the rule of law and public interest. ${ }^{54}$ In other words, the Attorney General has a duty to ensure that government action is in keeping with the values of the Constitution and the greater public good. As such, it seems appropriate that the Attorney General would have a subsidiary duty to refrain from adopting a litigation strategy in which procedural mechanisms are used as barriers to public interest standing cases.

52 Paul Vayda, 'Chipping away at Cost Barriers: A Comment on the Supreme Court of Canada's Trial Lawyers Decision' (2015) 36 Windsor Review of Legal and Social Issues 207; Mark Aronson, Matthew Groves and Greg Weeks, Judicial Review of Administrative Action and Government Liability (Thomson Reuters, $6^{\text {th }}$ ed, 2017) 594-6, specifically concerning access to representation.

53 [2014] 3 SCR 31

54 See Kent Roach, 'Not Just the Government's Lawyer' (2008) 31 Queen's Law Joumal 598; Allan Hutchinson, "In the Public Interest": The Responsibilities and Rights of Government Lawyers' (2008) 46 Osgoode Hall Law Journal 105; Debra McAllister, 'The Attorney General's Role as Guardian of the Public Interest in Charter Litigation' (2002) 21 Windsor Yearbook of Access to Justice 47. 
The importance of this understanding of special Crown ethical duties in relation to civil litigation flows from the fact that, if it were not to exist, the Attorney General would be able to represent the protection of the rule of law and public interest while simultaneously having the license to undermine them. It also flows, by analogy, from the fact that in specific legal settings (criminal and family law, for example) the Crown is said not to act as a 'zealous advocate' but rather as a 'neutral' officer of the Court. ${ }^{55}$ In Boucher $v$ The Queen, ${ }^{56}$ the Supreme Court characterised the role of the Crown prosecutor in these terms:

It cannot be over-emphasized that the purpose of a criminal prosecution is not to obtain a conviction; it is to lay before a jury what the Crown considers to be credible evidence relevant to what is alleged to be a crime. Counsel have a duty to see that all available legal proof of the facts is presented: it should be done firmly and pressed to its legitimate strength, but it must also be done fairly. The role of prosecutor excludes any notion of winning or losing; his function is a matter of public duty than which in civil life there can be none charged with greater personal responsibility. It is to be efficiently performed with an ingrained sense of the dignity, the seriousness and the justness of judicial proceedings. ${ }^{57}$

While similar constraints do not apply to the Crown in its role as a litigant in civil matters (pursuing damages for breach of contract, for example), in all these settings, Crown counsel remain 'guardians of the public interest' ${ }^{\prime}{ }^{8}$ The position of the Crown in civil matters involving the Charter (or other constitutional provisions) would appear to be a hybrid. The reasons for the constraints in criminal and family matters may not apply, but the model of the Crown as a zealous advocate also seems at odds with the mix of public interest, accountability, and rule of law imperatives operating in Charter settings.

This duty of the Crown to act in the public interest in Canada is arguably analogous to the Australian duty of the government to be a 'model litigant'. The Commonwealth is only to pursue litigation if it is convinced it is the best course, and based on reasonable grounds. ${ }^{59}$ On a practical level, the Commonwealth's obligations include the duty to pay legitimate claims, not cause undue delay, avoid relying on 'technical' arguments, and not take advantage of a claimant who lacks the resources to litigate a legitimate claim. ${ }^{60}$

The Crown's duty to act in the public interest (or be a model litigant) is particularly relevant and important when the government is dealing with vulnerable parties, where the government has a higher standard of conduct. Adam Dodek has pointed to parens patriae, child protection, expropriation, charities, and dealings with Indigenous peoples (Honour of the Crown) as instances of this higher standard. ${ }^{61}$ As public standing cases will involve vulnerable parties, it is arguable that the Crown should adopt strategies that seek to prevent unfairness towards such parties (discussed further below).

55 The Rules of Professional Conduct of the Law Society of Upper Canada <https: / $/$ www.lsuc.on.ca/list.aspx?id=671> set out the following:

5.1-3 When acting as a prosecutor, a lawyer shall act for the public and the administration of justice resolutely and honourably within the limits of the law while treating the tribunal with candour, fairness, courtesy, and respect.

[1955] SCR 16.

Ibid 23-4.

For discussion, see New Brunswick v Rothmans Inc (2009) 352 NBR (2d) 226, [33]

Attorney-General of Australia, Legal Services Directions 2017, 29 March 2017, s 4.2 ('LSD 2017').

Ibid app B.

Dodek, above $n$ 7, 26 . 


\section{B Public Funding}

The federal government has historically (and will now again) ${ }^{62}$ provided 'financial assistance for important court cases that advance language and equality rights guaranteed under Canada's Constitution'. ${ }^{63}$ In fact, the modernised Court Challenges Program (CCP) has expanded its scope of rights and will now accept challenges to 'fundamental freedoms, democratic rights and rights with respect to life, liberty and security of the person'. ${ }^{64}$

As such, it is clear that the government has an interest in ensuring that the rights of Canadians are respected and that those with legitimate claims are afforded the support they need to have their position heard. In light of this commitment, it would seem inconsistent and hypocritical for the Attorney General to make use of procedural mechanisms, such as summary judgment and motions to strike, in order to undermine cases brought forward with government funding. Further, due to the fact that all cases funded by the CCP have undergone a screening by a panel of experts and have been selected on their merits, any attempts to dismiss the case on procedural grounds should be seen as acts of hindrance, just as Commonwealth lawyers have a duty not to cause unnecessary delay. 65

\section{Flexibility in Charter Procedures-Guidance from the Supreme Court}

Recognizing that litigation can have public importance beyond the narrow dispute between the parties, Canadian courts, particularly the Supreme Court, have been especially flexible in the application of civil procedure in Charter litigation. This is strikingly apparent in the progressive and flexible approach to public interest standing, mootness, and interim cost awards, justified on access to justice grounds. Throughout all of these examples, it is apparent that when a poorly resourced party is up against the government, flexibility is necessary. A paramount consideration should be that matters should not be beyond the scope of judicial review due to procedural hurdles.

For instance, in British Columbia v Okanagan Indian Band and Little Sisters Book and Art Emporium $v$ Canada, the Court established the test for awarding interim costs in public interest litigation. The test does indeed have a high threshold - the claimant must show: 1) that the litigation would be unable to proceed without the costs; 2) the claim is prima facie meritorious; and 3) that the issues transcend the interests of the litigant, are of public importance, and have not been previously resolved. ${ }^{66}$ However, the very existence of such a mechanism to support important public interest cases suggests a strong interest on behalf of the courts to ensure the advancement of constitutional rights.

62 Court Challenges Program of Canada, Reinstatement News (February 2017)

<www.ccppcj.ca/en/news.php>.

63 Court Challenges Program of Canada, About CCP (February 2017)

<www.ccppcj.ca/en/about.php>.

64 Court Challenges Program of Canada, above n 62.

65 LSD 2017 sch B s 2(a).

66 British Columbia (Minister of Forests) v Okanagan Indian Band [2003] 3 SCR 371, 399-400 [40] (LeBel J); Little Sisters Book and Art Emporium v Canada (Commissioner of Customs and Revenue) [2007] 1 SCR 38, 47-64 [2]-[44] (Bastarache and Lebel JJ). 
In any event, costs awards ought not to act as a 'chilling effect' on citizens seeking to ensure that their government behaves constitutionally. ${ }^{67}$ The discretionary nature of costs awards and the unique nature of Charter litigation means that even the losing party can be awarded its costs in public interest litigation ${ }^{68}$ and/or the winning party can be awarded all of its costs. ${ }^{69}$

Further, in Downtown Eastside, the Court revised the requirements for public interest standing, adopting a 'purposive and flexible approach to applying the three factors' developed in its earlier trilogy of Thorson, ${ }^{70} \mathrm{McNeil}^{71}$ and Borowski: ${ }^{72} 1$ ) whether there is a serious justiciable issue raised; 2) whether the plaintiff has a real stake or a genuine interest in it; and 3) whether, in all circumstances, the proposed suit is a reasonable and effective way to bring the issue before the courts. ${ }^{73}$ In particular, the Court in Downtown Eastside reformed the way in which the third element of the test was to be applied, moving from it as a 'strict requirement' to one that should also be considered purposively and flexibly. ${ }^{74}$ While, much like interim cost awards, the Court has established a high standard for public interest standing, the adoption of a flexible approach that is premised on a 'cumulative weighing' of the factors is a sign that the Court has an interest in allowing meritorious claims to succeed.

Finally, the Court has frequently heard 'moot' appeals even when the dispute between the parties has ceased. While it normally a waste of judicial resources to hear a moot appeal, it can be a very prudent use of judicial resources to decide Charter matters likely to re-arise in litigation. The clarification in the law can be a 'stitch in time to save nine'. Moreover, there are frequently parties willing to defend or challenge the constitutionality of particular government action even after a particular dispute concerning the constitutional matter is moot. As such, courts will decide 'moot matters' in the constitutional law realm if resolution of a legal issue is in the public interest. ${ }^{75} \mathrm{By}$ example, in $M v H$, the Supreme Court determined the constitutionality of a family law statute even when the affected parties had reached a settlement. Though there was no more dispute between $\mathrm{M}$ and $\mathrm{H}$, the Court of Appeal's declaring the statute unconstitutional affected thousands of other families so certainty was warranted. ${ }^{76}$ This is not a carte blanche for courts to decide moot issues - for example, the Supreme Court refused to hear an equality-focussed challenge to the constitutionality of abortion statutes after the statutes had been declared unconstitutional on procedural fairness

67 See, eg, the decision of Justice Sharpe in Edwards v Law Society of Upper Canada (1998) 156 DLR $\left(4^{\text {th }}\right) 348$. He gives a similar overview from an academic perspective in Justice Robert J Sharpe, 'Access to Charter Justice' (2013) 63 Supreme Court Law Review 3.

68 See eg, B(R) v Children's Aid Society of Metropolitan Toronto [1995] 1 SCR 315, 327 [26] (Deschamps J); Conseil scolaire francophone de la Colombie-Britannique v British Columbia [2013] 2 SCR 774, 802 [64] (Wagner J); Sharpe, above $n 67$.

69 Carter v A-G (Canada) [2015] 1 SCR 331, 393-5 [138]-[143].

70 Thorson $v$ A-G (Canada) [1975] 1 SCR 138.

71 Nova Scotia Board of Censors v McNeil [1978] 2 SCR 662.

72 Minister of Justice (Canada) v Borowski [1981] 2 SCR 575.

73 Downtown Eastside [2012] 2 SCR 524, 546-53 [37]-[51] (Cromwell J).

74 Ibid 550 [45]. See Matt Malone, 'Standing in the Way: Comparing Constraints on Access to Justice After the Liberalization of Public Interest Standing in Canada and Israel' (2017) 46 Advocates' Quarterly 451.

75 See, eg, Borowski [1989] 1 SCR 342, 361 (Sopinka J).

$76 M v H[1999] 2$ SCR 3, 44-5 [44] (Cory and Iacobucci JJ). 
grounds and while the government was contemplating a replacement. ${ }^{77}$ But there is no question that the doctrine of mootness is relaxed in Charter litigation, given that public and private litigation differ in important ways.

Overall, it seems clear that the Court, through its evolution of mechanisms to support public interest litigation, has an interest in the advancement of Charter rights for Canadians. As such, it would seem inconsistent with this general promotion of public interest cases for the Attorney General to adopt litigation strategies that seek to prevent claimants from advancing their claims.

\section{THE IMPACT OF PROCEDURAL TACTICS ON CHARTER LITIGATION}

\section{A Procedural Mechanisms Can Undermine the Development of Charter Rights}

As should be evident from the above, we agree that procedural mechanisms, such as motions to strike, are important tools in the civil litigation process, including applications under the Charter. They are designed to allow parties to avoid the expense and anxiety of non-justiciable, unmeritorious or inappropriate litigation, and/or abuses of the justice system, as well as the public resources and legitimacy which go into that system. ${ }^{78}$

It is important to understand, however, that these mechanisms are powerful and, when used improperly, they have the capacity to impede the understanding of Charter rights. As a potential example, in Tanudjaja $v$ Canada, a 'challenge to both Ontario's and Canada's housing-related law and policy under sections 7 and 15 of the Charter, ${ }^{79}$ a motion to strike was upheld by the Ontario Court of Appeal. The claimants alleged that various actions and inactions of the provincial and federal governments had led to their dire housing circumstances and, as such, violated their rights of security of the person and equality. The claimants amassed a very substantial evidentiary record, but once the majority of the Court of Appeal upheld the motion judge's dismissal of the case on the grounds that the claim was non-justiciable, ${ }^{80}$ the merits of the Charter claim, and the evidence underlying it, received no judicial consideration.

Cases like Tanudjaja demonstrate the potentially devastating effect of the Crown's procedural discretion (coupled with the Court's own jurisprudence on justiciability and related doctrines). The dismissal of the claim on justiciability grounds at the outset prevented the admissibility of an evidentiary record on the issue and, possibly, set a precedent that such general issues as a right to housing are not within the realm of the courts. While the majority of the Court of Appeal in Tanudjaja expressed reservations on the generality of the applicant's claim (leaving open, for example, that specific public housing schemes or legislation could be subject to a Charter analysis), the chilling effect may be real, as such judgments may subsequently be cited for broad propositions about the Court's approach to Charter rights. ${ }^{81}$ The fact that anyone alleging that the Charter

Borowski [1989] 1 SCR 342.

Sinha, Sossin and Meguid, above $\mathbf{n} 6$.

Ibid 1.

Tanudjaja (2014) 123 OR (3d) 161.

81 See the press coverage of Tanudjaja, eg, Laurie Monsebraaten, 'Housing for All Not a Right: Court of Appeal Rules in Rejecting Charter Challenge', Toronto Star (online), 1 December 2014 
includes a right to housing will, almost by definition, be a poorly resourced person, decreases the likelihood that claims such as this will be litigated. Though such a claim may not be tenable in Australian courts, the Commonwealth has a similar duty to not take advantage of a poorly resourced party. ${ }^{82}$

In the end, while it is open to debate as to whether or not such issues are wholly political and non-justiciable, there is no denying that the unseen evidentiary record was crucial to the claimants' arguments in Tanudjaja. Whether or not the motion to strike in this case could have been sustained, ${ }^{83}$ the motion completely undermined the claim by preventing the claimants from being able to make use of the very materials that would allow them to convince the court. Further, even if the record had failed to convince the court, its very presence could have been helpful in determining the scope of the Charter rights at issue, and providing guidance in subsequent cases. ${ }^{84}$ In her dissenting opinion, Justice Feldman noted how clarity in the law in this area could help further parties. ${ }^{85}$ Instead, the decision may result in a chilling effect for prospective litigants.

\section{B When Procedural Mechanisms are Not Successful in Undermining Public Interest Claims, There Can be Significant Advancements in Charter Rights}

The advancement of Charter rights will often require a trial and the use of an evidentiary record. This is often due to their complexity and the need to establish causal connections between the actions of government and the harms experienced by the claimants. As such, the use of motions to strike carry a particular potential to thwart the development of Charter case law.

However, when these motions are dismissed by the courts in order to allow meritorious claims to advance, there can be positive consequences for the scope of Charter rights. For instance, in Jane Doe $v$ Metropolitan Toronto (Municipality) Commissioners of Police, Justice Henry dismissed the defendant's motion to strike out the claims of negligence and violations of sections 7, 15, and 28 of the Charter. ${ }^{86}$ In Jane Doe, the Court clarified that novelty alone should never be a ground for striking a claim as disclosing no cause of action. As a result, unlike in Tanudjaja, the claimants were enabled to put forward an evidentiary record at trial and establish the grounds for their position. In the end, the court found in favour of the claimant, holding that the police failed to provide the claimant with information vital to the security of her person, and that they neglected to do so based on a 'stereotypical discriminatory belief that as a woman she and others like her would become hysterical and panic and scare off an attacker ${ }^{\prime}{ }^{87}$ As

\footnotetext{
<https://www.thestar.com/news/gta/2014/12/01/housing for_all_not_a_right_court_of appeal_rules_in_rejecting_charter_challenge.html>.

82 LSD 2017 app B.

83 Cf Sinha, Sossin and Meguid, above n 6; Kennedy and Rowe, above n 44.

84 Sinha, Sossin and Meguid, above n 6. Kennedy does not disagree with this proposition though questions whether the value was worth the cost in Tanudjaja itself. Kennedy believes the matter was justiciable but, unlike Sossin, he believes that the underlying claim was clearly implausible and the pleading manifestly failed to disclose a cause of action: Kennedy and Rowe, above $n 44$.

85 Tanudjaja (2014) 123 OR (3d) 161, [67]-[68]

86 (1989) 58 DLR (4th) 396 (Supreme Court of Ontario - High Court of Justice).

87 Jane Doe $v$ Metropolitan Toronto (Municipality) Commissioners of Police (1998) 39 OR (3d) 487 (Court of Justice (General Division)).
} 
such, the case helped to expand the scope of sections 7 and 15 as well as the obligations of the police under the Charter.

\section{The Purpose and Value of Public Interest Standing and its Connections to Justiciability}

Public interest standing was not developed in order to create a narrow exemption to standing law. Rather, the aim of public interest standing has been to facilitate the judicial review of the validity of government action where to refuse standing might provide the Crown with constitutional immunity. ${ }^{88}$ We argue a similar framework should apply more broadly to procedural discretion - at least in the context of Charter test cases aimed at recognizing novel rights or notably new approaches to existing rights. To properly develop Charter jurisprudence, these kind of constitutional arguments need to reach the Court on their merits. ${ }^{89}$ This may require a pragmatic consideration of the (lack of) resources held by parties likely to allege a particular Charter violation.

Consider the challenge brought by the Canadian Bar Association in British Columbia asserting that the Charter guaranteed a right to legal aid in civil cases (earlier case law had established such a right in criminal law contexts - and had enlarged this right to some civil areas which were analogous to those criminal law settings). ${ }^{90}$ The British Columbia Supreme Court held that the applicants had not raised a specific constitutional breach as a result of a statute or executive action, but rather the failure of British Columbia to establish and fund a civil legal aid scheme:

However, in the case at bar, there is no challenge to legislation or to administrative action said to be ultra vires. Instead, there is a challenge attacking a failure to legislate or a failure to have a scheme in place that meets appropriate constitutional criteria as contended by the CBA. This is a significant distinction. Instead of considering a specific statute or a specific administrative act or expenditure for constitutional compliance, this case would ultimately require the court to define a constitutionally valid civil legal aid scheme and order its provision by the defendants.

The plaintiff correctly submits that the principles governing public interest standing must be applied in a 'liberal and generous manner'. In Canadian Council of Churches, Cory J. stated that 'the post-Charter era calls for a liberal and purposive approach to standing'. However, he also emphasised that the approach must remain balanced (at 250 ). In my view, the balanced approach will not be served by removing the requirement that the 'serious issue' must relate to invalidity of legislation, or to a public act undertaken without or in excess of statutory authority.

In the case at bar, there is no challenge to a specific governmental decision, act, or statute. The case cannot be characterised as raising an issue with respect to the limits of statutory, administrative, or executive authority. The challenge is to the funding, content, administration, operation, and effect of an entire public program that invokes various federal and provincial statutes, ministries, agencies, and non-governmental entities and actors. $^{91}$

88 Lorne Sossin, 'The Justice of Access: Who Should Have Standing to Challenge the Constitutional Adequacy of Legal Aid?' (2007) 40(2) UBC Law Review 727, 734.

89 Ibid 731.

90 See New Brunswick (Minister of Health and Community Services) $v$ G(J) [1999] 3 SCR 46.

91 Canadian Bar Assn v British Columbia (2006) 59 BCLR (4th) 38, [45]-[47] (BCSC), affd (2008) 76 BCLR (4th) 48 (BCCA), leave to appeal to the Supreme Court of Canada denied [2008] SCCA No 185 . 
The CBA never had the opportunity to demonstrate that the Charter includes a right to civil legal aid as it was denied standing. As this case demonstrates, procedural steps within test case litigation can create, in effect, the actual boundaries of judicial review. Justiciability needs to be seen not only through doctrinal boundaries of subject-area jurisdiction, but also as limits on judicial review as a result of the capacity and resources of those bringing test cases. This approach leads to new principles which can (and, we argue, should) be brought to bear on the procedural discretion of the Crown. As we elaborate in the final section, in light of the Crown's status in Charter cases, there should be limits on its discretion to seek procedural remedies that do not apply to other parties. ${ }^{92}$

\section{TOWARDS A NEW APPROACH}

In our view, it is appropriate to recognise that the difference in the resources, position and ethical framework of the Crown in relation to Charter cases ought to lead to a concomitant difference in approach to procedural justice. The Crown is under no obligation to accede to every Charter claim, and indeed, Crown lawyers are under a duty to advance the best arguments available to the Crown in relation to such claims. Those arguments may sometimes include procedural motions - particularly where the Crown believes judicial resources are not well spent on the matter (including, for example, because it appears to be vexatious or frivolous). Where the Crown seeks to deny an argument on the merits to a Charter matter because it raises a novel argument or extends an existing Charter right beyond its current scope, caution is warranted in our view. We would frame the duty on the Crown as ensuring the development of Charter rights is not obstructed.

While a detailed elaboration of this Crown duty of constraint should be developed in consultation with some of the stakeholders involved (Crown lawyers themselves, representatives of the applicant Charter bar, legal regulators, client groups, and so forth), we believe a point of departure should include three threshold questions:

1. Is the Charter challenge brought in good faith, with plausible arguments?

2. Would the potential procedural remedy sought by the Crown make it less likely that the applicant's or a similar challenge could be pursued due to the applicant's or others' limited time, resources and capacity?

3. Would the potential procedural remedy sought by the Crown thwart the opportunity of the Court to develop Charter rights, including the boundaries of or limits to those rights?

Where the answer to all three of these threshold questions, or even the first one as well as one of the other two, is affirmative, we believe the Crown should exercise its discretion not to proceed with the procedural challenge, or at a minimum, to have the procedural challenge considered concurrent to the merits of the challenge so a Court would have all the evidence and argument before it in advance of deciding on the procedural challenge. In some cases, this may mean greater Crown resources will have to go into defending an action. But this is consistent with the Crown's duty to act in the public interest and as a model litigant. ${ }^{93}$

92 Sossin, above n 88, 741.

93 Dodek, above n 7; LSD 2017 sch B. 
On this basis, a Charter claim like Tanudjaja could very well have been permitted to proceed. The claim was certainly brought in good faith, and its arguments around a declaratory remedy on governments to develop a plan to address the right to housing struck many observers (including the dissenting judge on the Ontario Court of Appeal) as plausible. The limited budgets of participating organizations and transient nature of applicants who lacked housing would meet the second prong of the threshold. And, in the end, the development of the Charter around social and economic rights generally, and the right to housing specifically, has been thwarted (at least for now). ${ }^{94}$ The CBA Charter claim seeking a right to civil legal aid, however, may be seen differently. While its claim was brought in good faith and certainly met the plausibility standard, it is less clear that the Canadian Bar Association falls into the same category in terms of limited time, resources and capacity. This standard must of course turn on the circumstances of particular cases, but as a general proposition, a large and well-funded organization of professionals with a long-term policy goal around the Charter may well not attract the special duties of constraint on the Crown developed above.

We would not limit the application of this framework of justiciability and access to justice to Charter cases alone - by analogy, a similar approach might be relevant in other constitutional settings - particularly involving the rights of Indigenous peoples under s 35(1) of the Constitution Act 1982, human rights cases against the Crown, and in other administrative law settings where similar dynamics are in play.

We should add that different considerations arise where it is the applicants seeking to use a procedural mechanism to short-cut a consideration of the evidence and argument in a Charter case. In other words, the rationale for the Crown duty does not apply equally in the context of Charter claimants. The asymmetry in resources and public interest duties results in an asymmetry in procedural considerations as well. This dynamic was illustrated by the 2015 decision in Allen $v$ Alberta. ${ }^{95}$ In Allen, the Alberta Court of Appeal found that the appellant's attempt to adjudicate the constitutionality of s 26(2) of the Alberta Health Care Insurance Act ${ }^{96}$ through summary judgment was inappropriate. Rather, the court held that the trial judge was correct to refrain from applying the precedent of Chaoulli ${ }^{97}$ as the issues in the case were complex, nuanced, factually sensitive, and raised genuine issues requiring a trial. ${ }^{98}$ The court did note, however, that 'there are undoubtedly cases where the binding authority is so clearly on point and definitive that a full trial is not required'.$^{99}$ In order to determine whether or not this is the case, a number of factors must be considered, including: '(a) the scope, (b) the pedigree, (c) the clarity of the precedent, and (d) the precise constitutional provision that is engaged'. ${ }^{100}$

As such, the case appears to establish a multi-step test for determining whether or not summary judgment can be used to determine the constitutionality of legislation or

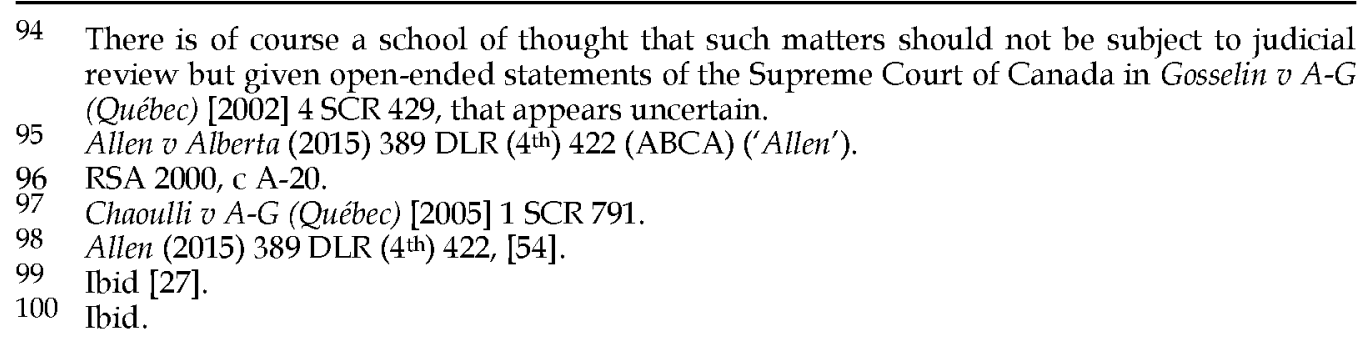


government action. At the core of the test is whether or not a full evidentiary record is necessary; the less clear-cut the issues and the precedent's commentary on the issues (this test necessitates precedent), the more likely it will be that a full evidentiary record will be necessary. The test is important as it seems to establish quite a high bar for using summary judgment on issues of constitutionality. While this may well be relevant as a general proposition, our approach would see an even higher threshold applied where such motions are brought by the Crown.

\section{CONCLUSION}

We have pursued two arguments in this brief article- one far-reaching and one modest. The first and far-reaching argument is that the principles of justiciability should not be understood in the abstract, but rooted in the lived experience of litigants. Thus, a matter that in principle could be subject of adjudication, but which in practice never would be because of the procedural tactics available to the Crown in a particular jurisdiction, should in our view be considered as part of the justiciability analysis. The resources parties actually possess must also be considered relevant and a matter should not, in practice, become beyond the scope of judicial review due to procedural obstacles. Justiciability, in this sense, is a multi-dimensional set of boundaries, closely related to access to justice concerns more generally, not a one-dimensional inquiry into the subjectmatter of a dispute.

The second and more modest argument is that a duty of restraint in raising procedural hurdles should be among the factors that informs Crown discretion in Charter litigation. ${ }^{101}$ This is a logical corollary to the justiciability concerns inherent to Charter litigation.

It is often said that Canadian constitutional law is best understood as a living tree. While we believe this metaphor remains apt, trees often need to be tended in order to thrive. This is particularly true when the tree is young, and before its roots are deep enough so that it can survive harsh weather. In Canada, the Charter is only 35 years old and its roots may not be deep enough to weather a storm that could be anything from a constitutional crisis to legislative malaise. Our prime gardeners are our courts. When someone calls for the gardener's help, the gardener should not be reluctant to come.

101 See, eg, Matthew A Hennigar, 'Conceptualizing Attorney General Conduct in Charter Litigation: From Independence to Central Agency' (2008) 51(2) Canadian Public Administration 193. 
